through an accident. His widow and two daughters came to England expecting to find friends, but these were on the point of returning to Australia. Being without advisers bere, they were robbed of nearly all they had by a fraudulent trustee, and have had to strive for a maintenance by letting their house out in apartments and by teaching. The mother, however, has been suffering for eighteen months from gastric ulcer, and requires the constant attendance of one of the daughters, so that one only can go out to teach, and their resources have consequently run down to the point of exhaustion. A grant of $£ 20$ has been made from the Irund, the maximum which can be allowed for any single case, $\mathfrak{E} 10$ of which has been given at once, while the remainder is to be paid in monthly instalments. But this just falls short of what is required to give these poor ladies another chance. Twenty or thirty pounds more would redeem a raluable pianoforte, which would enable the girl kept at bome in attendance on her mother to earn something by giring music lessons, and this would probably suffice to maintain them.

Inder such circumstances I have felt justified in departing from my rule of not asking for aid for individual cases, and in placing the facts before the profession. I shall be happy to take charge of anything which may be sent for these ladies. At the same time I trust that the Fund will not suffer, relieving as it does more than 150 deserving and urgent cases yearly, besides giving over fifty annuities to aged members of the profession.

I am, Sir, your obedient servant,

$$
\text { W. H. BROADDENT. }
$$

34, Seymour-street, Portman-square, W., July 31st, 1885 .

\section{MILD-BED MORTALIY IN LONDON MATERNITY HOSPITALS.}

To the Editor of THE LANCET.

StR, - Under this heading Dr. Duncan writes in THE LANCET of Aug. 1st, calling in question the accuracy of Dr. Priestley's statement, made upon my authority at the last meeting of the Obstetrical Snciety, that the mortality at Oueen Charlotte's Hospital between the dates of Feb. 14th, $188 \pm$, and July 1st, 1885, was only 1 in 1100 consecutive cases. $\mathrm{He}$ indirectly assigns as a reason for doubting my assertion the great divergency there is between the mortality under Drs. Williams and Champneys at a similar institution and that at Queen Charlotte's. To be logical, Dr. Duncan should doubt Drs. Williams and Champneys' statements, as there are many maternities which show a higher death-rate than theirs-indeed the majority of maternities do. I never knew before that the greater mortality at Vienna than London Was an argument against the correctness of the RegistrarGeneral's annual reports.

I beg to refer both Dr. Duncan and Dr. Williams to IIr. Wynter Blyth for an explanation of his most excellent quarterly reports. My object in naming the latter gentleman is, if I am correctly informed, that he quoted from these reports in order to refute Dr. Priestley at the above meeting. Did it never occur to either of these gentlemen that there are infants in a lying-in hospital, and that some might accidentally happen to be females, and that death is not a respecter of sexes? In conclusion, did it not strike Dr. Duncan that the reason $I$ was so careful in giving the dates between which the 1100 cases were delivered was that there might have been some deaths antecedent to Feb. 14th, 1834, in that year? and also that Queen Charlotte's Lying-in Hospital is a public institution, with public records open at all times to the inspection of any governor of the hospital? Am I demanding too great an effort on Dr. Duncan's part when I ask why he did not ask some governor then (by his own statement he had the list before him) to call and request the secretary to show the death certificate book, or why he did not constitute himself a governor by a three guinea subscription, before recklessly rushing into print and impugning the veracity of a member of the hospital traff?

I am informed that even Dr. Braxton Hicks has not sscaped haring the results of his private practice called in ruestion. 1 am proud to find myself in such good company, and only regret that his figures are more difficult of proof than mine, which half an hour's inspection of the death ryister at the registrar's office next door but one to Queen Charlotte's Hospital can verify, and show how recklessly Dr.
Duncan has endeavoured to cast a doubt upon the statements made by Dr. Priestley at the aforesaid meeting of the Obstetrical Society, on the authority of yours truly,

W. C. Griag, M.D.,

Physician to Queen Charlotte's Hospital

Curzon-street, Mayfair, August 11th, 1885.

\section{ENGIISII ARRANGEMENTS FOR THE RECEPTION OF CIIOLERA.}

To the Editor of THE LANCET.

SIR,- May I be permitted to draw attention to an important gap in our lines of defence against this probable invader?

Our first line is exclusion from our shore of developed and suspicious cases. This is liable to be penetrated at many points. Our second is the sperial management of the cases which have pierced our first line. Upon the effectiveness of this special nursing our protection from the spread of the disease mainly rests. Once this is thoroughly broken, the disease runs unrestrained.

Whence can we obtain nurses properly instructed on the points specially necessary? On the arrival of casual cases at hotels or at home where are the instructions to guicle the public upon these points? I am informed that we camnot rely on obtaining much, if any, supply for cholera cases from the so-called nursing institutions. Very few of these nurses for ordinary cases know the special measures requisite for annihilating this contagium. The hospitals of the Asylums Board and the vestries and unions will soon absorb all the better class of nurses. We have no properly skilled nurses ready and waiting for the first arrivals; yet this is the key of the situation. Moreover, we have few, if any, for those secondary cases who will not or cannot be removed to hospitals, nor for cases before removal. The proper attention to the needs of the affected is one thing, but the prevention of extension, viewed broadly, is a more important matter. To meet this may I throw out a suggestion, as a beginning, that nurses specially instructed should be brought together in depôts or centres, under proper supervision, to which medical men and others could send; that the direction of these centres should be made widely known in each district; that, in view of a heavy demand, volunteers might be attached to these, living in the district and ready at short notice; and that one or two special nurses should be in residence at all the large terminal hotels and at others frequented by travellers. Printed rules as to treatment of the discharges of confirmed and suspicious cases also should be widely circulated among the public.

The importance of this subject must be my apology for occupying so much space. I am, Sir, yours truly, George-street, Hanover-square, August 1885. BRAXTON HrCKS.

\section{THE COMPARATIVE DANGER OF VARIOUS AN AESTHETICS.}

To the Editor of THF LANCET.

SIn,-On page 1147 of THE LANCET for June 30th, a correspondent is disposed to depreciate statistics going to show that the deaths from chloroform are far more numerous than those from ether, and seems to defy anyone to produce such statistics. Dr. Andrews of Chicago, in the Medical Examiner of that city for May, 1870 , collected 92,815 cases of etherisation, with 4 deaths ( 1 in 23,204 ) ; 117,078 chloroform, with 43 deaths ( 1 in 2723 ); chloroform and ether mixed, 11,172 cases, with 2 deaths ( 1 in 5588); and 7000 of methylene, with 1 death ( 1 in 7000). Dr. Coles of Virginia has collected 152,620 cases of chloroform inhalation, with 53 deaths, or 1 in 2873; and 10,000 of methylene bichloride, with 2 deaths, or one in 5000 . Your English expert, Dr. B. W. Richardson, gave a high rate of mortality to chloroform. In eight hospitals (Norwich, Lynn, Stafford, Wolverhampton, Newcastle-under-Lyme, Brighton, Birmingham-General and Queen's Hospitals), from 1848 to 1864 , it was administered in 17,000 cases, with 1 death only; while from 1865 to 1869 there were 7500 cases and 6 deaths! In six other hospitals (Lincoln, Bath, Cambridge, Oxford, Reading, and Nottingham) the same periods show respectively 17,900 cases, with 3 leaths, and 2765 cases, with 1 death-being a total of 
35,165, with 11 deaths, or 1 in 3197. Chisholm quotes Ker as saying that in the first twenty-eight years of its use at the Royal Infirmary at Edinburgh chloroform was responsible for only 2 deaths; and during the first ten years of this period he estimates the cases as 36,500 , with 1 death only. Elser of Strasburg gives us statistics embracing 16,000 cases of chloroformisation, with no death at all. Dr. Kidd of London saw it used 10,000 times, with no fatal cases; and Richardson himself saw it used in the same city 15,000 times before he met with his first fatal result. Clover records 3000, and no death; and Billroth 12,500 before his first death. Hunter McGuire, of Richmond, Va., reports 18,000 cases, and no death, during the late Rebellion. Chisholm used chloroform 6000 times, with no death, and estimates its mortality at $\frac{10}{200 \pi}$. During the Crimean war the French used chloroform 30,000 times, with at least 2 deaths. ${ }^{1}$ In the English army, out of 12,000 cases, McLeod heard of 1 fatal case. ${ }^{2}$ During the Rebellion, 1861-65, it was estimated that chloroform was used 80,000 times, of which 7 cases are known to have proved fatal ${ }^{3}$ this would be 1 in 11,448. Nussbaum* had 15,000 cases and Kœnig about 7000 , all without accident; while Kappeler himself had 1 death in 5000 cases. Bardeleben ${ }^{5}$ had seen more than 30,000 cases of chloroform inhalation before the year 1876, with no death; but during that year there were 4 fatal cases out of only 1200 ! This gave, up to 1879 , a mortality of 4 in about 84,000 cases. In St. Bartholomew's, in $1875-80,{ }^{8}$ chloroform was used 4810 times with 2 deaths, or 1 to 2405 ; and ether was used 6440 times, with 2 deaths, or 1 to 3220 . Summing up, we have-Ether, 99,255 times, 6 deaths $=\frac{1}{10542}$; chloroform, 492,235 times, 84 deaths $=\frac{1}{5860}$.

I am, Sir, yours truly,

Nelson B. DE Srzer, M.D. \& Bac. Sc. Brooklyn, New York, Aug., 1885. (Neo-Eboracensis).

\section{Y I N G D E C A R A T I O N. To the Editor of THE LANCET.}

SIR,-In the Notes of Cases in Obstetric Jurisprudence of August 8th, Case 12, page 244, Dr. Braxton Hicks writes as follows: "In cases where the only evidence is derived from one who is dead it is impossible to convict unless the dying statements are taken by a magistrate." I would point out that this is a very prevalent mistake, and one calculated often to cause a serious failure of justice. It cannot be too clearly known, especially to medical men, that, provided the declarant conscientiously believes that he has no hope of recovery, anyone may take down his dying declaration, and such declaration properly attested is admissible as evidence just as much as if taken on oath by a magistrate. I am, Sir, yours truly,

Chas. Gross, F.R.C.S. Eng.

St. Saviour's Infirmary, Walworth, S.E., Aug. 8th, $188 \overline{\text {. }}$

\section{THE W A T R S OF TARA P P. To the Editor of THE LANCET.}

SrR,-In your issue of the 1st inst. is a notice of the baths of Tarasp (Unter Engadine), to which, with your permission, I will add that the principal hotel of the locality is situated in a deep valley on a level with the river Tun, and therefore in a somewhat close and confined situation. Visitors should ask about Schuls, a village near Tarasp-Bad, but on much higher ground, where there is first-rate hotel accommodation, and to which the physicians of the baths, Dr. Rillias and Dr. Pernisch, pay daily visits. There are also large baths maintained by the authorities of the district and the chief chalybeate springs. For beautiful scenery and an extensive view this place is unrivalled.

Your contributor speaks also of Carlsbad as hot and stuffy, but I have not found it so even in July, and the guide-books speak of it as "a great-coat place" for the mornings and evenings are very cool. The town lies in the valley of the Tepel, near its confluence with the Egen, but I have never found it unbearable, whilst its physicians, though they admit some amount of bad drainage, tell you

1 Medical Times and Gazette, May 7th, 1859, p. 485.

2 Ibid., July 10th, 1858, p. 40 . 3 Circular, No. 6, p. 87. 4 Kappeler, Anæsthetica, p. 124.

5 Medical Times and Gazette, Aug. 2nd, 1879.

6 British Medical Journal, Jan. 15th, 1891, p. 103. "visitors never die here," and, in fact, they very rarely doon Justice is, we all know, the first object of your paper, 80 i beg an insertion of these few lines.

I am, Sir, yours obediently,

Mandeville-place, W., August 6th, $1885 . \quad$ FreDERICK SLMYS.

\section{LIVERPOOL.}

(From our own Correspondent.)

PRECAUTIONS AGAINST CHOLERA.

THE communication between this city and Spain wolld of itself be sufficient to justify the adoption of erery precaution in order te prevent the possibility of any spread of cholera. In addition to this there is now the danger of the disease being imported from Marseilles. I is only bare justice to our local authorities to say that owing to their efforts last year Liverpool was, humant speaking, saved from an epidemic of cholera, several case of that disease having undoubtedly occurred on borr vessels between Marseilles and this port; but owing to the timely destruction of all infected clothing and bedding, an the thorough disinfection of the vessels, further progengse was arrested. Dr. Stopford Taylor, the medical officer of health, is also port sanitary officer, and is most ably seconded by Dr. Hope, assistant medical officer of health to the city and port, and a competent staff of sanitary offcials Liverpool still contains many streets, spread over its whote extent, in which the inhabitants are thickly clustered to. gether, living in a half-starved, drunken, and dirty state, where cholera, if it once appeared, would commit frightfilt ravages. It is therefore satisfactory to learn that erery precaution is being adopted, and especially to prohibit the landing of rags from any Spanish port. Should any resel arrive from an infected port she will be thoroughly es amined by the medical and sanitary officials, and not allowed pratique until the former are satisfied that thete are no traces of contagion on board.

THE SCARCITY OF WATER.

Notwithstanding recent heavy showers much anxiety prevails as to the scarcity of water, though the supply is ofl off for the twelve hours five p.m. to five a.m. At the weelly meeting of the Water Committee on the 10th inst. it wis stated that from the statistics of the supply of water made up to the 4th inst., there was a deficiency of 1239 million gallons for the present year.

THE ASSIZES.-CASES OF MEDICO-LEGAL INTEREST,

An elderly man was convicted of attempting to murler several of his children at St. Helens by administering to them oxalic acid. Under prompt medical treatment ther all recovered. Mr. Frank T. Paul, lecturer on forengil medicine and toxicology at the Liverpool University College found oxalic acid in the vomited matters. The case rios clearly proved, and the prisoner was sentenced to twent? years' penal servitude.

A German sailor, twenty-two years of age, was chargel with having murdered the second mate of the British barat Paragon while on a voyage The crime was committed with an axe, on which NI, Pal found blood-marks. A severe wound was inflicted on th back of the deceased's head, to which he succumbed trets days after. The jury found the prisoner guilty of mat slaughter, and he was sentenced to ten years' penal serrt? tude. There were also several cases of rape and indeetl assault on females, in all of which Mr. Justice Manist inflicted very severe sentences, remarking that these crny were very common both in this and other counties.

\section{EDINBURGH.}

\section{(From our own Correspondent.)}

MR. ERICHSEN'S CANDIDATURE,

Mr. Erichsan's committee are working energeticall i? favour of his return as member for the Edinburgh al St. Andrews Universities. They are carrying out as actirits programme of personal canvass as the usages of acadr etiquette will permit. $\Lambda$ printed letter has been forration 